\title{
Characterization of technological properties of matá-matá wood (Eschweilera coriacea [DC.] S.A. Mori, E. odora Poepp. [Miers] and E. truncata A.C. Sm.) by Near Infrared Spectroscopy
}

\author{
Cristiano Souza do Nascimento ${ }^{(1)}$, \\ Claudete Catanhede do \\ Nascimento ${ }^{(2)}$, \\ Roberto Daniel de Araújo (2), \\ Jose Carlos Rodrigues Soares ${ }^{(3)}$, \\ Niro Higuchi ${ }^{(4)}$
}

The aim of this study was to determine the technological properties (chemical, mechanical and physical) of Eschweilera sp. woods using near infrared spectroscopy (NIRS). NIR spectroscopy proved to be efficient for chemical analysis (extractives, lignin and carbohydrates) and physical-mechanical testing (moisture content, basic density - BD, modulus of elasticity - MOE and modulus of rupture - MOR) of wood, providing a powerful tool for use in sustainable forest management activities in the Amazon. Wood samples from three trees of each Eschweilera species were collected from the Experimental Station of Tropical Forestry/INPA/Brazil. Specimens were extracted from the cross-sectional area $(20 \times 20 \times 30 \mathrm{~mm})$ in the direction sapwood-heartwood. NIR spectra $(4,000-$ $10,000 \mathrm{~cm}^{-1}$ ) were then obtained from the samples (moisture 12\%) using Fourier-transform spectrometry. The Partial Least Squares (PLS) regression prediction models for the chemical, mechanical and physical properties of Amazonian woods were used for quantification. The results for total extractives (both in toluene and ethanol) and hot water solubility showed a maximum extractive concentration of $7.66 \%$ and $3.13 \%$ for $E$. odora (yellow matámatá), including several compounds with low molecular weight, such as resins, gums, terpenes, alkaloids, flavonoids, and tannins. The highest concentration of phenolic substances (tannins) was found in $E$. Truncata (black matá-matá, $10.00 \%$ ). The macrocomponents (primary metabolism) of Eschweilera species were in the range of $44.20-46.33 \%$ for cellulose and $28.89-31.21 \%$ for lignin. Mineral compounds (ash) were quantified in concentrations $<0.70 \%$. The predictive results for the physical and mechanical properties of matá-matá wood are in the standard range for tropical woods. The higher calorific value (HCV) varied from 4.993-5.033 $\mathrm{cal} \mathrm{g}^{-1}$ and the BD from 0.78-0.88 $\mathrm{g} \mathrm{m}^{-3}$. Regarding moisture, the highest content was observed in $E$. truncata $(13.46 \%)$. Values for mechanical resistance were in the range of 14,253-17,447 MPa for MOE and 146.04-175.73 MPa for MOR, with the greatest strength attributed to $E$. truncata wood. The values obtained for the wood technological properties of $E$. coriacea (white matá-matá), E. odora (yellow matá-matá) and E. truncata (black matá-matá) were compatible with those obtained by destructive determination of tropical species and also for other species of the genus Eschweilera.

Keywords: Eschweilera, Amazonian Woods, Wood Chemistry, Physico-mechanical Properties, NIR Spectroscopy, Forest Management

\section{Introduction}

The Amazon rainforest is considered one of the largest sources of tropical timber in the world, with a production at the end of 2014 of around 31 million $\mathrm{m}^{3}$ from the Brazilian states of Acre, Amazonas, Mato Grosso and Pará (OIMT 2015). This scenario would be satisfactory if this production originated from Sustainable Forest Management Programs that combine planned exploitation with legal, economic and ecological principles (Balboni et al. 2018). At this level, 6000 botanical species with arboreal habit have already been cataloged; however, the commercial species are limited to a number of 100 (Garcia et al. 2012).

Selective exploration in the Amazon of the so-called "commercial woods" is restricted to a dozen species with a large di- ameter, which dramatically reduces the size of their populations and may generate scarcity of wood provision from these species in the next future. On the other hand, widely abundant species with smaller standard diameter are neglected and/or relegated to the background, as their potential for use and indication for markets is not yet known (Fróes et al. 2019). Many of these species are suitable for forest management and are not commercialized due to lack of knowledge of their properties; these include Eschweilera sp. and Couratari stellata (Lecythidaceae), Bixa arborea (Bixaceae), Helicostylis pedunculata (Moraceae), Inga sp. and Tachigali chrysophylla (Fabaceae), among others (Balboni et al. 2018, Freitas \& Vasconcellos 2019).

The timber species known in the Amazon 

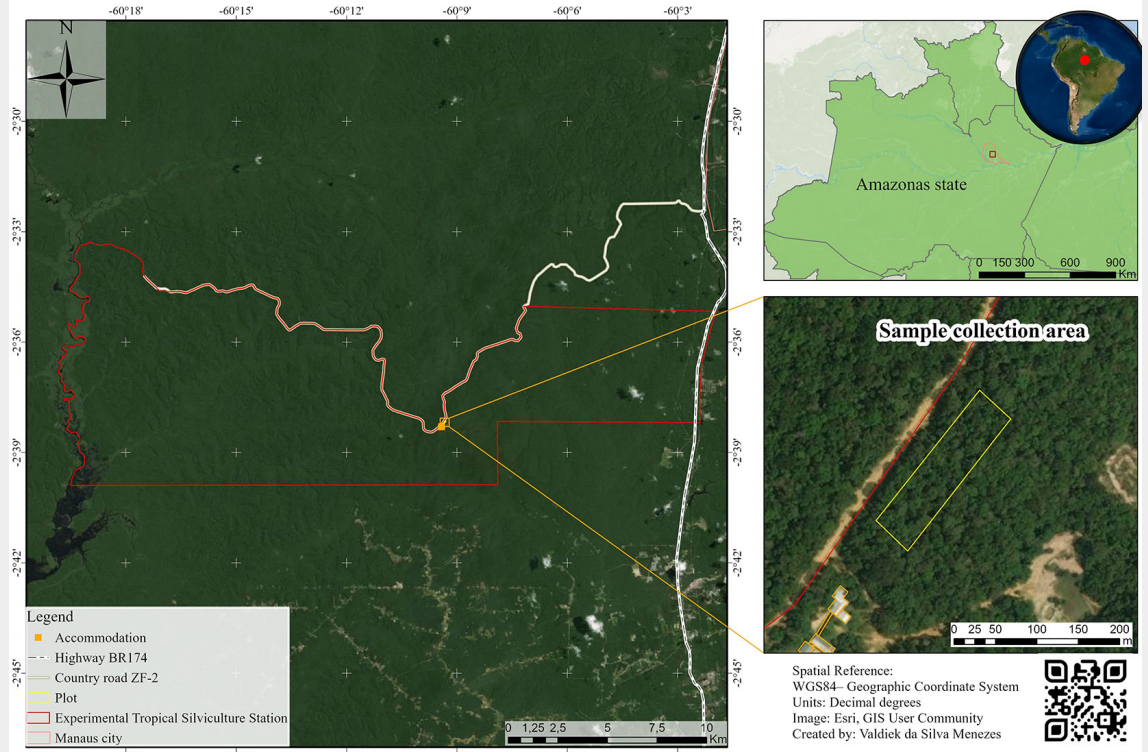

Fig. 1 - Geographic location of the sample collection area. research and industry for quality control in recent years is near-infrared spectroscopy (NIRS), which makes it possible to correlate the spectra with various properties of wood. This technique is considered robust since it combines mathematical modeling with chemistry (chemometrics), associating the physical, mechanical and biological properties of wood (Varejão et al. 2012, Tsuchikawa \& Schwanninger 2013, Mancini et al. 2019). It is believed that the NIRS methodology is the primary tool for technological characterization of wood that can be safely and quickly applied to sustainable forest management in the Amazon. In view of this, this study aimed to determine the physical, mechanical and chemical properties of matá-matá woods (Eschweilera coriacea [DC.] S.A Mori, E. odora Poepp. [Miers] and E. truncata A.C. Sm.) using near infrared spectroscopy NIRS.

\section{Materials and methods}

\section{Study site}

The research was carried out with species from terra firme secondary forest at INPA/ Brazil's Experimental Tropical Silviculture Station ( $02^{\circ} 35^{\prime} 55.5^{\prime \prime} \mathrm{S}, 60^{\circ} 02^{\prime} 14.8^{\prime \prime} \mathrm{W}$ ), located at km 23 of the ZF-2 highway (Fig. 1), accessed from km 50 of Highway BR-174 (Manaus- Boa Vista). In a 1-hectare plot (100 $\times 4 \times 25$ m sub-plots), 128 trees of different species were inventoried, with emphasis on the species of Eschweilera, which is the dominant genus in the region (Central Amazonian rainforest) and is promising for commercial purposes. Nine trees were selected at random for exploration, based on similar characteristics between individuals of the same species, such as diameter at breast height (DBH) and height. These trees were in the $25 \mathrm{~cm} \leq \mathrm{DBH} \leq 50 \mathrm{~cm}$ diameter class and visual analyzes of the health status of each tree were also carried out. Discs of $10 \mathrm{~cm}$ thickness were cut at DBH from three individuals of each species,

Tab. 1 - NIR modeling data used to predict the technological properties of Eschweilera woods. (n): number of samples; (Rc²): Determination coefficient - Calibration; (RMSEC): Root mean square error of calibration; (RMSEP): Root mean square error of prediction; (RPD): Ratio of performance to deviation.

\begin{tabular}{llrrrrrrrr}
\hline Models & Treatment /smoothing & $\begin{array}{c}\text { Spectral } \\
\text { range }\left(\mathbf{c m}^{-1}\right)\end{array}$ & $\mathrm{n}$ & Rc $^{2}$ & RMSEC & RMSEP & RPD & $\begin{array}{c}\text { Uncer- } \\
\text { tainty \% }\end{array}$ & Standard range \\
\hline Extractives & $2^{\text {nd }}$ derivative Norris & $7500-4540$ & 120 & 0.99 & 0.09 & 0.42 & 4.09 & 0.82 & $1.08-17.30 \%$ \\
\hline Polyphenols & $2^{\text {nd }}$ derivative Norris & $6100-5900$ & 120 & 0.95 & 2.48 & 5.68 & 4.66 & 9.06 & $0.13-13.60 \%$ \\
\hline Hot water & $2^{\text {nd }}$ derivative Norris & $7500-4540$ & 120 & 0.98 & 0.68 & 0.07 & 3.22 & 0.12 & $0.17-13.90 \%$ \\
\hline Lignin & $2^{\text {nd }}$ derivative Norris & $6070-5000$ & 60 & 0.99 & 0.46 & 5.43 & 3.01 & 10.04 & $21.56-44.35 \%$ \\
\hline Cellulose & $2^{\text {nd }}$ derivative Norris & $5000-4000$ & 60 & 0.99 & 0.12 & 3.85 & 3.05 & 4.55 & $35.00-54.85 \%$ \\
\hline Ash & $2^{\text {nd }}$ derivative Savitzky-Golay & $8450-7300$ & 120 & 0.97 & 0.11 & 0.47 & 5.01 & 0.61 & $0.04-3.00 \%$ \\
\hline Moisture & $2^{\text {nd }}$ derivative Norris & $6070-5500$ & 60 & 0.99 & 0.15 & 1.30 & 3.53 & 1.40 & $10.14-15.51 \%$ \\
\hline Higher calorific value & $1^{\text {st }}$ derivative Savitzky-Golay & $7450-4090$ & 90 & 0.94 & 49.30 & 62.40 & 3.99 & 4.01 & $4000-5263 \mathrm{cal} \mathrm{g}$ \\
\hline Basic density & Untreated $^{\text {st }}$ & $10000-4000$ & 64 & 0.91 & 0.07 & 0.10 & 3.69 & 11.02 & $0.40-1.00 \mathrm{~g} \mathrm{~cm}^{-3}$ \\
\hline Modulus of elasticity & $1^{\text {st }}$ derivative Savitzky-Golay & $5360-4000$ & 120 & 0.90 & 1.25 & 1.91 & 4.09 & 4.36 & $7060-19420 \mathrm{MPa}$ \\
\hline Modulus of rupture & $2^{\text {nd }}$ derivative Savitzky-Golay & $6020-5075$ & 120 & 0.89 & 16.10 & 28.00 & 5.82 & 12.20 & $46.68-200.42 \mathrm{MPa}$ \\
\hline
\end{tabular}


Eschweilera coriacea (white matá-matá), E. odora (yellow matá-matá) and E. truncata (black matá-matá), from which specimens $(20 \times 20 \times 30 \mathrm{~mm})$ were manufactured from the cross section, in the direction of the sapwood. Ten specimens were extracted from each individual to obtain the NIR spectra. Samples from each individual were sent to the Wood Anatomy Laboratory (COTI/INPA) for confirmation of species identification in the field.

\section{Analysis procedures}

Spectra in the near infrared region were obtained from the radial and tangential planes of the specimens (moisture 12\%) using a Fourier-Transform spectrometer (FTNIR/Termo Fisher Scientific, Antaris II model). The system uses the "Result Integration" software that operates in the 4,000 to $10,000 \mathrm{~cm}^{-1}$ range, with 16 scans and 8 $\mathrm{cm}^{-1}$ resolution. Three readings were taken from each side of the sample to obtain a mean spectrum that represents the sample (Nascimento et al. 2017).

Partial Least Squares (PLS) regression models were developed by Nascimento \& Varejão (2012) and Nascimento et al. (2016) to predict the chemical, physical and mechanical properties of Amazonian woods. These models are based on the correlation of the NIR spectra (wood) with test results by the traditional method (destructive methodology), using the TQ Analyst ${ }^{\mathrm{TM}}$ software. This enables subsequent results for wood properties to be obtained through non-destructive means, i.e., the NIR spectrum of the wood is obtained and correlated with the chemometric data, with the new spectrum assessed for similarity with the data set.

The data set (NIR spectrum $\times$ reference value) is separated into two groups, the first is used to calibrate the equation $(2 / 3$ data) and the second to validate the model ( $1 / 3$ data). The tested models are composed of a set of raw data, with mathematical treatment of $1^{\text {st }}$ and $2^{\text {nd }}$ derivative tests and also the option to apply filters or not. Tab. 1 shows the chemometric parameters used in the predictive models for technological properties, based on 1200 samples from 40 different wood species from the Amazon rainforest, with each species represented by three individuals and 10 specimens.

All of the models were built from original data obtained by the traditional methodology, as described in: (i) determination of the total extractives content - ethanol/toluene (D1105-96/2013, ASTM 2013); (ii) determination of the content of total polyphenols and tannins (Barbosa et al. 2006); (iii) determination of solubility in hot water (D1110-84/2013, ASTM 2013); (iv) Determination of lignin content (D1106-96/2013, ASTM 2013); ( $v$ ) determination of the crude cellulose content (Halward \& Sanchez 1975); (vi) determination of ash content (D1102-84/2013, ASTM 2013); (vii) determination of moisture (D2016-74/1983, ASTM

Tab. 2 - Results of chemical properties of Eschweilera woods by non-destructive methodology. Each value is an average of four repetitions. (SD): Standard deviation, Means followed by the same letter do not statistically differ ( $p>0.05)$ after Tukey test.

\begin{tabular}{|c|c|c|c|c|c|c|c|}
\hline Species & Stats & Extractives & Polyphenols & $\begin{array}{c}\text { Hot } \\
\text { water }\end{array}$ & Lignin & Cellulose & Ash \\
\hline \multirow{3}{*}{ 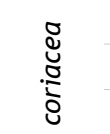 } & Max. & 6.37 & 6.18 & 1.42 & 31.83 & 47.48 & 0.64 \\
\hline & Min. & 5.55 & 5.77 & 0.93 & 30.57 & 44.81 & 0.41 \\
\hline & Average & $5.85^{a}$ & $5.92^{b}$ & $1.25^{b}$ & $31.14^{\mathrm{a}}$ & $46.33^{a}$ & $0.49^{\mathrm{a}}$ \\
\hline نس & SD & 0.45 & 0.23 & 0.28 & 0.64 & 1.37 & 0.13 \\
\hline \multirow{4}{*}{ 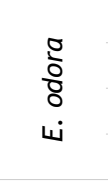 } & Max. & 7.66 & 3.01 & 3.13 & 30.66 & 46.43 & 0.65 \\
\hline & Min. & 5.81 & 1.63 & 2.81 & 24.88 & 43.46 & 0.42 \\
\hline & Average & $6.48^{a}$ & $2.09^{c}$ & $2.76^{a}$ & $28.89^{a}$ & $44.64^{\mathrm{a}}$ & $0.55^{\mathrm{a}}$ \\
\hline & SD & 1.02 & 0.79 & 0.39 & 3.48 & 1.57 & 0.12 \\
\hline \multirow{3}{*}{ 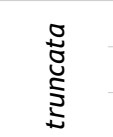 } & Max. & 6.45 & 10.00 & 2.14 & 31.67 & 45.73 & 0.71 \\
\hline & Min. & 5.59 & 7.06 & 1.75 & 30.86 & 43.29 & 0.66 \\
\hline & Average & $6.08^{a}$ & $8.78^{a}$ & $1.90^{b}$ & $31.21^{\mathrm{a}}$ & $44.20^{a}$ & $0.69^{\mathrm{a}}$ \\
\hline نسا & SD & 0.44 & 1.53 & 0.21 & 0.42 & 1.33 & 0.03 \\
\hline
\end{tabular}

2013); (viii) determination of the higher calorific value - HCV (D2015-00/2000, ASTM 2013); (ix) determination of basic density BD (NBR 7190/1997, ABNT 1997); (x) determination of the modulus of elasticity (MOE) and rupture (MOR) in static bending (555 - COPANT 1973).

\section{Statistical analysis}

The NIR spectra of the matá-matá woods (total of 90 samples) were applied in different models to predict the physical, mechanical and chemical properties. The results obtained were subjected to statistical analysis to obtain the mean, minimum and maximum values, as well as to analysis of variance and normality tests. When a statistically significant difference in the property being evaluated was found ( $\alpha=0.05$ ), the Tukey test (PAST v. $2.17 \mathrm{C}-\mathrm{Hammer}$ et al. 2001) was applied. At the end, a correlation matrix was obtained between the predicted properties. For this, the data that did not meet the assumption of normality were submitted to $\log _{10}$, square root and Box Cox data transformations to meet the assumption of Pearson's correlation analysis. For variables that did not meet the assumption of normality even after transformations, Spearman's correlations were applied. These analyzes were performed using the statistical software $R$ v. 4.0.5 (R Core Team 2020).

Tab. 3 - Result of the analysis of variance of the chemical properties of the different Eschweilera woods.

\begin{tabular}{lcccc}
\hline Variables & Sum of squares & Mean square & F & P-value \\
\hline Extractives & 0.6167 & 0.3083 & 0.6398 & 0.5599 \\
\hline Polyphenols & 67.4644 & 33.7322 & 33.4435 & 0.0006 \\
\hline Hot water & 3.4711 & 1.7355 & 19.1139 & 0.0025 \\
\hline Lignin & 10.4790 & 5.2395 & 1.2402 & 0.3542 \\
\hline Cellulose & 7.5783 & 3.7891 & 1.8514 & 0.2365 \\
\hline Ash & 0.0622 & 0.0311 & 2.8426 & 0.1354 \\
\hline
\end{tabular}

\section{Results and discussion}

\section{Chemical characterization}

The elucidation of the chemical characteristics of wood provides the basis for interpreting its properties in an engineering context, in order to better understand the strengths and limitations of this raw material. The results of the estimation of the technological properties of the matá-matá woods are presented in Tab. 2, Tab. 4 and the analysis of variance (ANOVA) in Tab. 3 and Tab. 5 .

The extractives in organic solvents (toluene and ethanol) and solubility in hot water showed maximum concentrations of $7.66 \%$ and $3.13 \%$ for Eschweilera odora (yellow matá-matá), where these compounds add up to more than $10 \%$ in dry mass of this species (Tab. 2). The analysis of variance (ANOVA) was applied to the extractives concentration and no overall significant difference among species ( $p=0.5599)$ was found. However, for water solubility, the existence of differences in mean values among species ( $p=0.0025-$ Tab. 3 ) was confirmed by the Tukey test, indicating that there is a difference in the concentration in E. odora (2.76\%) compared with $E$. coriacea (white matá-matá - 1.25\%) and $E$. truncata (black matá-matá -1.90\%).

A range of compounds with low molecular weight was found in the extractives, in- 


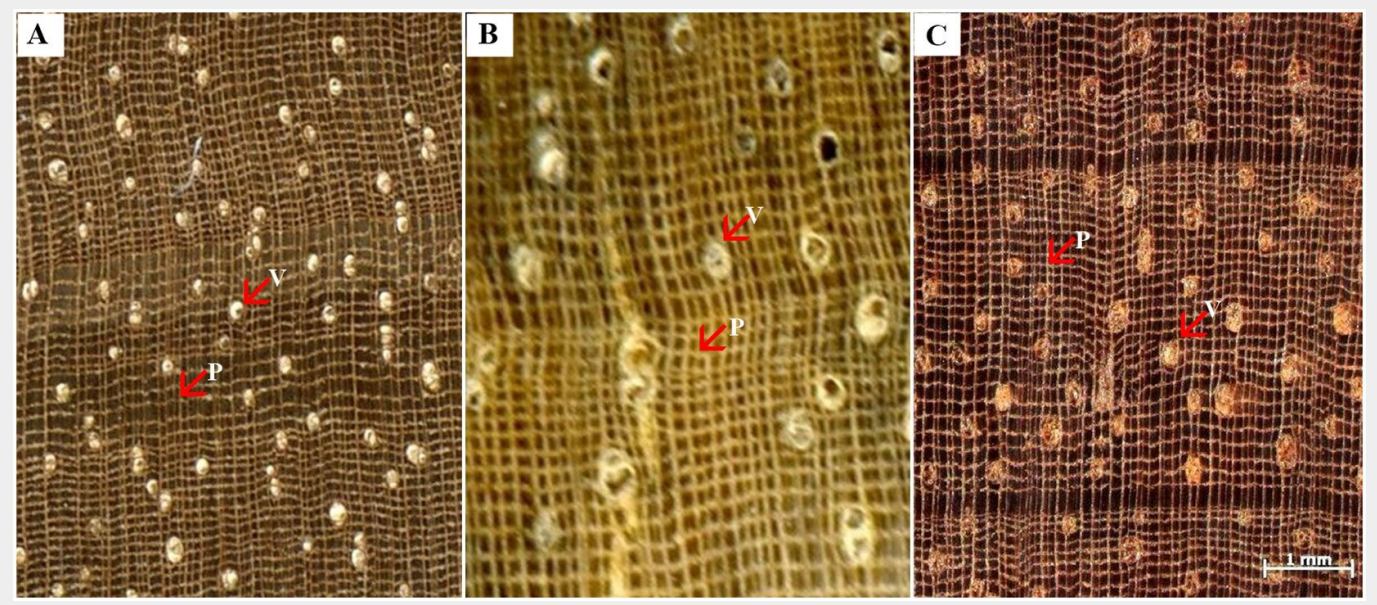

Fig. 2 - Cross-sectional view (10x) of matá-matá (Eschweilera sp.) wood samples. (A): E. coreacea; (B): E. odora; (C): E. truncata; (P): parenchyma; $(V)$ : vessels.

cluding resins, gums, terpenes, alkaloids, and flavonoids. Also within these compounds are several chemical classes of phenolic substances, such as tannins. The extraction quantification process uses, in general, nonpolar and/or low polar solvents (hexane, benzene and chloroform) that are responsible for the removal of resins, waxes and essential oils. Tolueneethanol, acetone, methanol and water, which are medium- to high-polarity solvents, carry a large amount of compounds such as flavonoids, tannins and sugars (Barbosa et al. 2006, Lovaglio et al. 2017). For tannins, a higher concentration was observed in the extractives of $E$. truncato $(10 \%)$. The Tukey test confirmed the formation of three classes of values for polyphenols and total tannins $(p=0.0006)$, with $E$. truncata (8.78\%) differing from the other two species and E. coriacea (5.92\%) displaying significant differences in relation to $E$. odora (2.09\%).

Secondary metabolites (extractives) can be found in the middle lamella, parenchymal cells, and vessels and voids in the $x y-$ lem tissue. The anatomical aspects of the three species of Eschweilera studied are presented in Fig. 2, where the similarity can be observed in the vasicentric paratracheal parenchyma and in lines $(P)$ and solitary vessels $(V)$ obstructed by organic substances (extractives).

The macrocomponents (primary metabolism) of Eschweilera species were in the range of $44.20-46.33 \%$ for cellulose and 28.89-31.21\% for lignin (Tab. 2). Despite this variation, no statistical difference was observed between the means of each species for these compounds (lignin: $p=0.3542$; cellulose: $p=0.236$ ). Comparing these results with data from the literature for tropical woods, it was found that these values fall within the standard range for species in the region (Silva \& Silva 1991, Fengel \& Wegener 2003). As for the mineral compounds present in the xylemic tissue, which in technology are quantified as ash (a product of carbonization), in the present study these were quantified in concentrations $<0.70 \%$, with no statistical difference among species $(p=0.1354)$.

Tab. 4 - Results of the physical and mechanical properties of Eschweilera woods by non-destructive methodology. Each value is an average of four repetitions. SD = Standard deviation. Means followed by the same letter do not differ statistically after Tukey test ( $p>0.05)$. (HCV): higher calorific value; (BD): basic density; (MOE): modulus of elasticity; (MOR): modulus of rupture.

\begin{tabular}{|c|c|c|c|c|c|c|}
\hline Species & Stats & $\begin{array}{c}\text { Moisture } \\
\text { (\%) }\end{array}$ & $\begin{array}{c}\mathrm{HCV} \\
\left(\mathrm{cal} \mathrm{g}^{-1}\right)\end{array}$ & $\begin{array}{c}\mathrm{BD} \\
\left(\mathrm{g} \mathrm{cm}^{-3}\right)\end{array}$ & $\begin{array}{c}M O E \\
(\mathrm{MPa} \times 1000)\end{array}$ & $\begin{array}{l}\text { MOR } \\
\text { (MPa) }\end{array}$ \\
\hline \multirow{3}{*}{ 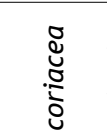 } & Max. & 12.66 & 5.094 & 0.83 & 16.570 & 153.78 \\
\hline & Min. & 12.52 & 4.972 & 0.71 & 14.310 & 145.28 \\
\hline & Average & $12.58^{b}$ & $5.033^{a}$ & $0.78^{a}$ & $15.337^{b}$ & $149.32^{b}$ \\
\hline نس & SD & 0.07 & 61.000 & 0.07 & 1.144 & 4.27 \\
\hline \multirow{4}{*}{$\begin{array}{l}\frac{0}{2} \\
\frac{0}{8} \\
\text { ن }\end{array}$} & Max. & 13.46 & 5.114 & 0.93 & 14.640 & 147.57 \\
\hline & Min. & 12.77 & 4.871 & 0.80 & 13.710 & 144.01 \\
\hline & Average & $13.21^{b}$ & $4.996^{a}$ & $0.88^{a}$ & $14.253^{b}$ & $146.04^{b}$ \\
\hline & SD & 0.38 & 121.650 & 0.08 & 484.390 & 1.83 \\
\hline \multirow{4}{*}{ 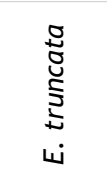 } & Max. & 13.80 & 5.135 & 0.91 & 18.310 & 176.35 \\
\hline & Min. & 13.11 & 4.849 & 0.74 & 16.300 & 174.81 \\
\hline & Average & $13.46^{\mathrm{a}}$ & $4.993^{a}$ & $0.81^{a}$ & $17.447^{\mathrm{a}}$ & $175.73^{a}$ \\
\hline & SD & 0.35 & 143.010 & 0.09 & 1.034 & 0.82 \\
\hline
\end{tabular}

Cellulose is the most abundant polysaccharide in nature. It is formed of a chain composed of glucose units joined by $1-\beta$, 4glycosidic bonds. Plant cell walls are compactly arranged in such a way that the fibers present clearly crystalline regions. Due to its chemical and physical properties, as well as its supramolecular structure, cellulose is linked to the volumetric contraction of the species (Silva \& Silva 1991, Varejão et al. 2012).

Lignin is another major component of wood. It is an amorphous, heterogeneous and predominantly aromatic polymer, which involves polysaccharides in the cell structure. It is characterized by the high number of $-\mathrm{OCH}_{3}$ and -OH groups, and its chemical structure differs depending on whether it comes from hardwood or coniferous wood. Lignified cell walls tend to contract less than non-lignified ones. Since lignin provides resistance to impact, compression and bending, it decreases water permeability, in addition to protecting against microorganisms by preventing the penetration of destructive enzymes into the cell wall (Fengel \& Wegener 2003, Sjöström 2013).

Extractives, or secondary metabolites, include a wide range of organic compounds, such as terpenes, fatty acids, aromatic compounds (mainly phenolic compounds) and vegetable oils. These substances have a physiological function in the tree, whether as a reserve material, for energy storage or antioxidant activity against environmental stressors, among others. They are responsible for certain characteristics of the wood, such as taste, color, flammability, and especially the natural resistance to $x y$ lophagous organisms (Kilic \& Niemz 2012).

In addition to macrometabolites and extractives, small amounts of mineral compounds are found in wood, which are absorbed from the soil during the growth of trees and deposited in the cell wall. In general, these compounds are analyzed in ash that is characterized as alkaline material (pH 8-13), formed by carbonates, salts and oxides of $\mathrm{Ca}, \mathrm{K}, \mathrm{Mg}, \mathrm{P}, \mathrm{Na}$ and $\mathrm{Si}$ (Serafimova et al. 2011, Sjöström 2013).

Castilho (1984) carried out the chemical 
characterization of Eschweilera iquitoensis wood (machimango colorado), a species from the Peruvian Amazon, using traditional destructive methodology, reporting values of $30 \%$ lignin, $8 \%$ total extractives and $1 \%$ ash. Moutinho et al. (2011), investigating matá-matá woods (E. amazonica, E. coriacea, E. idatimon and E. ovata) from the southeastern region of Pará (Brazil) recorded values from 23.40 to $30.80 \%$ for lignin content and extractives concentrations from $3.60 \%$ (white biriba, E. ovata) to $11.10 \%$ (E. coriacea). Nascimento et al. (2019), studying the chemical profile of extractives of tree species from the Lecythidaceae family of the Central Amazon, found total extractives levels ranging from 1.93\% (castanha sapucaia, Lecythis usitata) to $7.10 \%$ ( $E$. odora), and total polyphenols concentrations of $0.33 \%$ (white tauari, Couratari stellata) to $2.79 \%$ (tauari, Couratari guianensis).

\section{Physical and mechanical characterization}

The results of predictions for the physical and mechanical properties of matá-matá wood are presented in Tab. 4. The analysis of variance did not detect significant differences for the values of higher calorific value (HCV, $p=0.8936)$ and basic density ( $\mathrm{BD}, p=0.3889$ ) between the studied species, with the HCV ranging from 4.993$5.033 \mathrm{cal} \mathrm{g}^{-1}$ and BD from $0.78-0.88 \mathrm{~g} \mathrm{~cm}^{-3}$. As for moisture content, the highest value was observed for $E$. truncata (13.46\%). This was evidenced by the Tukey test with a significant difference ( $p=0.0284)$ when compared with the means of E. Coriacea (12.58 $\%)$ and $E$. odora (13.21\%). The same statistical difference was observed for modulus of elasticity (MOE, $p=0.0153$ ) and modulus of rupture (MOR, $p<0.0001)$, with a variation of 14.253-7.447 MPa and 146.04-175.73 MPa, respectively (Tab. 4, Tab. 5). It is worth mentioning that the values predicted for the properties are in the range for high density Amazonian woods (INPA/CPPF 1991, Balboni et al. 2018).

Kollmann \& Cotê Junior (1968) and Silveira et al. (2013) state that the physical and mechanical properties depend on the moisture content of the wood, with this variable being inversely proportional to $\mathrm{BD}$, $\mathrm{HCV}, \mathrm{MOE}$ and MOR, i.e., the greater the water content, the greater the interrelation of hydroxyls with cellulose and hemicellulose molecules, increasing dimensional instability and defects in pieces of wood and reducing the energy potential, as well as the biological and mechanical resistance of the wood. The statistical analysis indicated the formation of two moisture groups with lower (E. coriacea and E. odo$\mathrm{ra}$ ) and higher moisture content (E. truncata). Within this range, Silva et al. (2014) observed a moisture level of $12.16-14.22 \%$ when applying near infrared spectroscopy (NIR) to predict this property in wood waste from the Amazon.

The calorific value of wood is one of the
Tab. 5 - Results of the analysis of variance of the physical and mechanical properties of the different Eschweilera woods.

\begin{tabular}{lcccc}
\hline Variables & Sum of squares & Mean Square & \multicolumn{1}{c}{ F } & P-value \\
\hline Moisture & 1.2313 & 0.6156 & 6.8312 & 0.0284 \\
\hline HCV & 2.978 & 1.489 & 0.1146 & 0.8936 \\
\hline BD & 0.0124 & 0.0062 & 1.1069 & 0.3898 \\
\hline MOE & $15,823.089$ & $7,911.544$ & 9.0805 & 0.0153 \\
\hline MOR & $1,589.897$ & 794.948 & 107.3328 & 0.0000 \\
\hline
\end{tabular}

main parameters reflecting the energy production of this material, along with the concentration of chemical compounds, moisture and $\mathrm{BD}$. The Amazonian biome contains forest species that have not been studied for energy purposes, although energy production from wood is widespread, mainly for domestic use and for the production of charcoal for the steel industry. A study by Silva et al. (2020) used a traditional methodology to characterize the energy values of wood waste for the production of briquettes, finding high HCV values that ranged from $5.213 \mathrm{cal} \mathrm{g}^{-1}$ (angelim pedra, Hymenolobium petraeum) to $5.832 \mathrm{cal}$ $\mathrm{g}^{-1}$ (jatobá, Hymenaea courbaril). Moutinho et al. (2011) found lower values for several matá-matá woods (Eschweilera sp.), ranging from 4.438-4.758 $\mathrm{cal} \mathrm{g}^{-1}$. However, in one of the few studies using non-destructive prediction (NIR), Silva et al. (2014) characterized waste wood from the state of Amazonas (Brazil), finding HCV values similar to those of the present study, ranging from 4.608 (cedrinho, Scleronema sp.) to $4.928 \mathrm{cal} \mathrm{g}^{-1}$ (louro, Ocotea sp.).

One of the key variables for wood usage is density, which is closely related to chemical composition and anatomical structure (Kollmann \& Cotê Junior 1968, Vale et al. 2010). Applying the non-destructive methodology (NIR) on wood from Picea sitchensis (Sitka spruce), Pinus sylvestris (Scots pine) and 24 tropical species, Nuopponen et al. (2006) sought to establish the relationship between chemical constitution and wood density, concluding that tropical wood had greater density than spruce and pine woods, and also verifying that tropical species had a higher content of lignin in their composition than other woods.

Araújo et al. (2019), studying managed wood species in the Amazon and applying the traditional methodology, identified the predominance of wood with high density (murici, Byrsonima crispa, $0.71 \mathrm{~g} \mathrm{~cm}^{-3}$; piãozinho, Micrandropsis sclerorylon, $1.18 \mathrm{~g} \mathrm{~cm}^{-3}$ ). Within this range, Fróes et al. (2019) found mean values of $0.77 \mathrm{~g} \mathrm{~cm}^{-3}$ for E. truncata wood by applying the same (destructive) methodology, while Nascimento et al. (2017) determined the density of $E$. odora by NIR, obtaining mean values of $0.80 \mathrm{~g}$ $\mathrm{cm}^{-3}$. In the current study the matá-matá woods were classified as high density (BD > $0.70 \mathrm{~g} \mathrm{~cm}^{-3}$ ).

Knowledge of the mechanical properties of wood is essential for structural pur- poses. Balboni et al. (2018) characterized the physical and mechanical properties of the Amazonian woods Pseudopiptadenia psilostachya (timborana) and E. ovata obtained MOE values of $16,030-17,870 \mathrm{MPa}$ and MOR of 103.90-127.10 MPa, with the greatest resistance observed for Eschweilera wood. In the database of the Institute of Technological Research (IPT 2020), the tropical species Hymenaea courbaril is classified as a high resistance wood with MOR of 151.8 MPa and MOE of 17,062 MPa.

Predictive studies based on high-quality hardwoods are not as common. Araújo et al. (2019) used the Stress Wave Timer technique to determine the MOE of Amazonian woods, obtaining values from 11,049 (breu vermelho, Protium puncticulaton) to 14,201 MPa (Micrandropsis sclerorylon). In recent years, several studies have been developed to validate models based on NIR spectroscopy in order to predict the mechanical properties of solid wood. Andrade et al. (2010) determined the mechanical strength of Eucalyptus urophylla (red eucalyptus) wood by NIR spectroscopy and obtained MOR of $94.40 \mathrm{MPa}$ and MOE of 15,972.20 MPa. Schimleck et al. (2018) compared several NIR predictive models for six species of pines (Pinus caribaea, P. chiapensis, $P$. maximinoi, $P$. oocarpa, $P$. taeda and $P$. tecunumanii), where MOR ranged from 55.1570.13 MPa and MOE from 5,930.21-9,110.24 MPa. Also using spectroscopy, Mancini et al. (2019) recorded MOR values of 102.40 $\mathrm{MPa}$ and MOE values of 12,132.00 MPa for Castanea sativa (sweet chestnut). Yu et al. (2020) compared the mechanical properties of Quercus mongolica (mongolian oak) wood using NIR modeling and observed values for breaking strength in the range of 120.00 to $200.00 \mathrm{MPa}$ and resistance to elasticity from 12,000 to $18,000 \mathrm{MPa}$.

The non-destructive prediction method used for technological characterization of Eschweilera woods is entirely based on near infrared spectroscopy (NIRS), a tool based on vibrational spectroscopy. This involves the exposure of wood to electromagnetic radiation in the range of 4,000 to $12,000 \mathrm{~cm}^{-1}$, which allows the estimation of various attributes of wood based on the combination of chemical constituents with physical and mechanical properties by multivariate statistics and chemometrics. The technological properties of Eschweilera woods predicted by the NIR models in this study are within the standard range for 
Fig. 3 - Factorial distribution of the analyzed wood properties by PCA. (BD): Basic density; (MOE): Modulus of elasticity; (MOR): Modulus of rupture; (HCV): Higher calorific value.

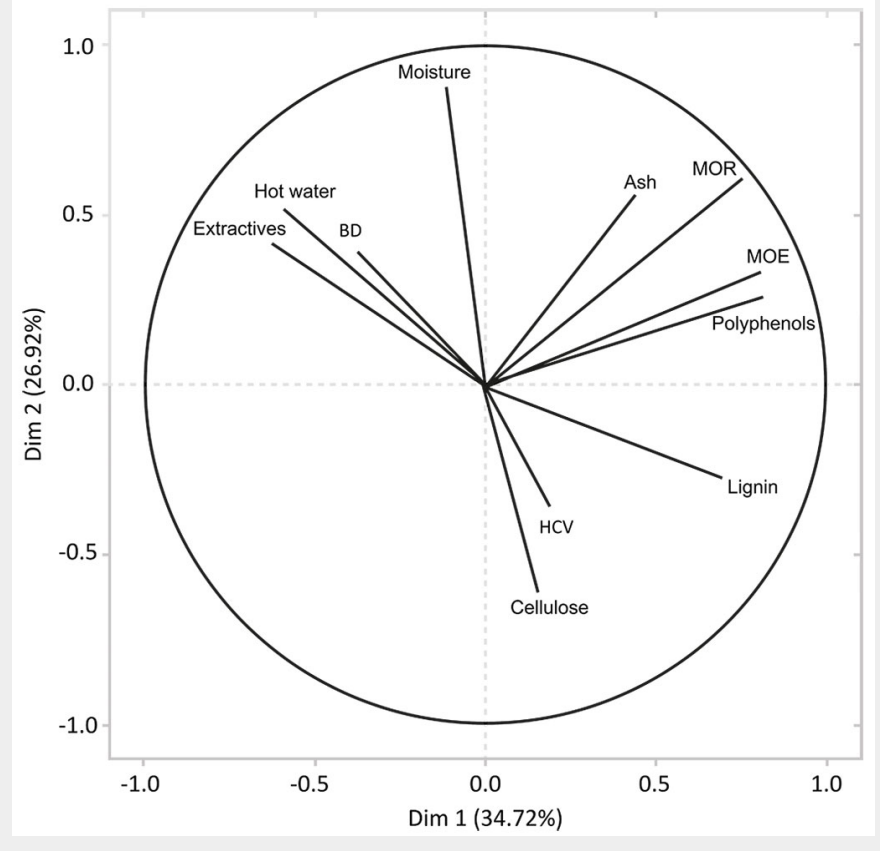

tropical woods based on traditional methods, thus proving the model accuracy in the variable predictions.

To investigate the possible biological relationships between the physical, mechanical and chemical characteristics of matá-matá wood, principal component analysis (PCA) was carried out based on Pearson's corre lation matrix (Fig. 3, Tab. 6). The first four components explained $86 \%$ of the total variation. Based on the $\mathrm{PC} 1$ and $\mathrm{PC} 2$ (ac counting for $62 \%$ of the total variation - Fig. $3)$, four groups of wood properties could be identified. Group 1 (G1) included ash, polyphenols, MOE and MOR; group 2 (G2) included cellulose, lignin and HCV; group 3 (G3) included BD, extractives and solubility in hot water; and group 4 (G4) included only moisture. Among the wood properties grouped in G1, MOR showed a highly sig which can be partly explained by the macro components of wood (cellulose and lignin). Fujimoto et al. (2008) stated that the $\mathrm{OH}$ group (linked to specific NIR bands) in the semicrystalline or crystalline regions of cellulose strongly affect wood resistance (MOR and MOE) in flexural tests. As regards the strong relationship of polyphenols with mechanical strength, little evidence is available in the literature. A possible explanation could be proposed here, as phenolic compounds present in extractives, such as highly reactive tannins, form intra and intermolecular hydrogen bridges with various compounds in the wood (Pizzi 2019). Similar to polyphenols, the correlation between ash and wood strength has been little studied, and could possibly be explained by the intramolecular interac-

Tab. 6 - Result of Pearson's correlation among all variables obtained from the relationships between chemical, mechanical and physical variables Eschweilera wood. (BD): Basic density; (MOE): Modulus of elasticity; (MOR): Modulus of rupture; (HCV): Higher calorific value. $(*)$ : For the correlation of this variable with the others, Spearman correlations were applied. (Class): strength of the correlation based on Callegari-Jacques (2003): moderate $(0.30 \leq r<0.60)$; strong $(r \geq 0.60)$.

\begin{tabular}{|c|c|c|c|c|c|}
\hline Properties & Variable 1 & Variable 2 & Pearson $r$ & $\mathrm{P}$-value & Class \\
\hline \multirow[t]{7}{*}{ Chemical } & Extractives & Cellulose & -0.47 & 0.2030 & Moderate \\
\hline & & $\mathrm{BD}$ & 0.46 & 0.2017 & Moderate \\
\hline & & Hot water & 0.36 & 0.3380 & Moderate \\
\hline & & $\mathrm{HCV}$ & -0.41 & 0.2780 & Moderate \\
\hline & Polyphenols & Lignin* & 0.33 & 0.3800 & Moderate \\
\hline & & MOE & 0.87 & 0.0020 & Strong \\
\hline & & MOR & 0.84 & 0.0040 & Strong \\
\hline \multirow[t]{2}{*}{ Mechanical } & MOR & Ash & 0.56 & 0.1130 & Moderate \\
\hline & & MOE & 0.90 & $<0.0001$ & Strong \\
\hline \multirow[t]{2}{*}{ Physical } & $\mathrm{BD}$ & Hot water & 0.30 & 0.4270 & Moderate \\
\hline & $\mathrm{HCV}$ & Ash & -0.33 & 0.3920 & Moderate \\
\hline
\end{tabular}

tions of carbonates, phosphates and silicates within the plant cell (Higuchi 1997).

Among the variables grouped in $\mathrm{G}_{2}$, the positive correlation of lignin and HCV is well known, especially in energy studies: the higher the lignin content, the greater the energy potential (HCV), as the higher the concentration of fixed carbon in the matrix, the stronger the glow when burned (Telmo \& Lousada 2011, Todaro et al. 2015, Silva et al. 2020). As for the cellulose/lignin connection, the correlation is negative (Fengel \& Wegener 2003). Regarding the G3 wood attributes, the extractives/BD association has been explained in several studies (Nascimento et al. 2017, Soares et al. 2018, Fróes et al. 2019), since high-density tropical forest species grow slowly in diameter, thus having time for greater deposition of compounds in the xylem (Silva \& Silva 1991, Chave et al. 2009). Conversely, pioneer species, which are generally fast growing, display low density and concentration of extractives (Vale et al. 2010, Kilic \& Niemz 2012).

Wood moisture (the only attribute included in G4) has an indirect correlation with most properties. For example, Silveira et al. (2013) studied the inverse correlation between moisture and $\mathrm{BD}$, with low density wood having a higher moisture content. In the energy industry using wood biomass, species with higher moisture content have a low HCV and consequently a lower energy yield (Silva et al. 2014, 2020). By assessing the influence of extractives on hydraulic architecture in tree species of the Central Amazon, Santos (2020) found that certain species evolved an adaptive strategy to face water stress, whereby a high moisture content was associated with a higher concentration of aqueous extractives.

The most significant correlations among the analyzed wood properties (Tab. 6) were found between MOR and polyphenols $(r=0.84, p=0.004)$, MOE and polyphenols $(r=0.87, p=0.002)$, and MOE and MOR $(r=0.90, p=0.000)$. The following sequence was obtained from the variables classified as moderate correlation: MOR/ ash $>$ Extractives/cellulose $>$ Extractives/BD $>$ Extractives/HCV $>$ Extractives/hot water $>$ Lignin/polyphenols $>\mathrm{HCV} / \mathrm{ash}>\mathrm{BD} /$ hot water. The largest contributions to these combinations are associated with extractives, polyphenols and MOR.

In recent studies on Amazonian woods, Silva et al. (2020) found significant correlations between extractives and $B D(r=0.56)$ as well as ash and HCV $(r=-0.58)$. Fernandes et al. (2017) found a significant correlation between extractives and hot water $(r$ $=0.550$ ), while Soares et al. (2018) working with Eucalyptus sp., also observed significant correlations between extractives and $\mathrm{BD}(r=0.48)$ and extractives and cellulose $(r=-0.563)$. Other studies showed correlations between chemical and physical variables in wood, including Moutinho et al. (2011) who reported a moderate correla- 
tion for the extractives/HCV combination ( $r$ $=-0.390$ ). It is worth mentioning that in all of these studies similar correlation trends were observed as in the present study.

As for physical properties, Moutinho et al. (2011) observed a correlation between BD and HCV $(r=0.360)$, while for mechanical properties, Fernandes et al. (2017) showed a highly significant relationship between MOE and MOR $(r=0.779)$, which is lower than that detected in this study $(r=0.902)$. MOE is a wood rigidity parameter that is highly and positively correlated with strength and therefore can be used to assess wood strength parameters like MOR (Liu et al. 2007).

\section{Conclusions}

In this study, chemical, physical and mechanical properties of the wood of Eschweilera coriacea (white matá-matá), E. odora (yellow matá-matá), and E. truncata (back matá-matá), estimated by NIR spectroscopy, were compatible with those obtained by the destructive determinations of tropical species and also with other species of the genus Eschweilera. Knowledge of the chemical composition and the distribution of chemical components in plant tissues is key to improve the use of wood and its commercialization in different industrial sectors, such as civil or naval construction, manufacture of furniture, boards and panels, etc.

The technological characterization of matá-matá woods by near infrared spectroscopy (NIRS) provided robust and satisfactory results generated in short time. Besides, in contrast to the traditional methodology, there is no need to destroy the sample and do not produce waste. Finally, PLS models used in this study to predict wood technological properties showed high performance with high determination coefficient (> 0.90) and RPD (ratio of performance to deviation > 3), and low calibration and prediction errors (RMSEC and RMSEP, respectively).

\section{Acknowledgements}

The authors thank the Coordenação de Aperfeiçoamento de Pessoal de Nível Superior - MEC/CAPES (Ph.D. Candidate CFT/ INPA to 88882.4444 19/2019-01); the MCTI/ CNPq/FAPEAM project "INCT Madeiras da Amazônia" for financial support; Jorge A. Freitas for the identification of the sample woods; and Ana Julia O. Godoy for reviewing the English text.

\section{Authors contribution}

All authors contributed to the design, results and discussion of this study. CSN and $\mathrm{CCN}$ are primarily responsible for the conception, design, analysis and writing of the manuscript. RDA produced and processed NIR spectral data. CSN performed the chemical, mechanical and physical analysis of the wood. JCRS edited the images and supported the statistical analysis. NH is the general coordinator of the project "INCT
Madeiras da Amazônia/MCT/CNPq/FAPEAM", which supported field activities and collection. CCN made a critical review of the paper content. Finally, all authors approved the final version of the manuscript.

\section{References}

ABNT (1997). Projeto de estruturas de madeira ABNT (NBR7190) [Design of wooden structures - ABNT (NBR7190)]. Associação Brasileira de Normas Técnicas - ABNT, Rio de Janeiro, RJ, Brazil, pp. 68. [in Portuguese]

Andrade CR, Trugillo PF, Napoli A, Vieira RS, Lima $J T$, Sousa LC (2010). Estimation of the mechanical properties of wood from Eucalyptus urophylla using near infrared spectroscopy. Cerne 16 (3): 291-298. - doi: 10.1590/S0104-7760201000 0300005

Araújo RD, Santos J, Nascimento CC, Nascimento CS, Barros SVS, Lima MP (2019). Surface roughness of Edge Glued Panels (EGP) of amazon grown species. Ciência e Agrotecnologia 43: e019119. - doi: 10.1590/1413-70542019430191 19

ASTM (2013). Annual book of ASTM standards. Section 4 - Construction, Volume 04.10 - Wood. American Society for Testing and Materials ASTM, West Coshohocken, PA, USA, pp. 1054. Balboni BM, Silva TS, Andrade FWC, Freitas LJM, Moutinho VHP (2018). Physical-mechanical characterization of two amazon woods coming from the second cutting cycle. Anais da Academia Brasileira de Ciências 90: 3565-3572. doi: 10.1590/0001-3765201820170845

Barbosa AP, Palmeira RCF, Nascimento CS, Feitoza D (2006). A chemical survey of central Amazonian Leguminosae species. I. Substances found in the bark of woody species. Fitos 1: 4757. [online] URL: http://revistafitos.far.fiocruz. br/index

Bieker D, Rust S (2010). Non-destructive estimation of sapwood and heartwood width in Scot's pine (Pinus sylvestris L.). Silva Fennica 44: 267273. - doi: 10.14214/sf.153

Callegari-Jacques SM (2003). Bioestatística: princípios e aplicações [Biostatistics: principles and applications]. Artemed, Porto Alegre, RS, Brazil, pp. 255 [in Portuguese] [online] URL: http:// pesquisa.bvsalud.org/portal/resource/pt/lil-598 026?lang=en

Castilho MEU (1984). Determinacion del poder calorífico de 20 especies florestales de la Amazonia peruana [Determination of the calorific value of 20 forest species of the Peruvian Amazon]. Revista florestal do Peru 12: 98-117. [in Spanish] [online] URL: http://cedinfor.lamolina. edu.pe/Articulos_RFP/Vol12_no1-2_84_(16)/vol1 2 art8.pdf

Chave J, Coomes D, Jansen S, Lewis SL, Swenson NG, Zanne AE (2009). Towards a worldwide wood economics spectrum. Ecology Letters 12: 351-366. - doi: 10.1111/j.1461-0248.2009.01285.x COPANT (1973). COPANT 555, método de ensayo de flexión estática [COPANT 555, static bending test method]. Comisión Panamericana de Normas Técnicas - COPANT, Buenos Aires, Argentina, pp. 10. [in Spanish]

Fengel D, Wegener G (2003). Wood chemistry, ultrastructure, reactions. Walter de Gruyter, Berlin, Germany, pp. 895.

Fernandes C, Gaspar MJ, Pires J, Alves A, Simões
R, Rodrigues JC, Silva ME, Carvalho M, Brito JE, Lousada JL (2017). Physical, chemical and mechanical properties of Pinus sylvestris wood at five sites in Portugal. iForest 10: 669-679. - doi: 10.3832/ifor2254-010

Freitas JA, Vasconcellos FJ (2019). Identificação de madeiras comerciais da Amazônia [Identification of commercial wood from the Amazon]. INPA, Manaus, AM, Brazil, pp. 70. [in Portuguese]

Fróes DF, Nascimento CC, Freitas JA, Silva GM, Araújo RD, Dantas GS, São Pedro Filho F (2019). Managing the technological potential of Eschweilera truncata A.C. Sm in the Amazon. International Journal for Innovation Education and Research 7 (11): 585-598. - doi: 10.31686/ijier.vol 7.iss 11.1912

Fujimoto T, Kurata Y, Matsumoto K, Tsuchikawa $S$ (2008). Application of near infrared spectroscopy for estimating wood mechanical properties of small clear and full-length lumber specimens. Journal of Near Infrared Spectroscopy 16: 529-537. - doi: 10.1255/jnirs.818

Garcia FM, Manfio DR, Sansigolo CA, Magalhães PAD (2012). Yield of Itaúba (Mezilaurus itauba) and Tauarí (Couratari guianensis) logs sawmill according to log quality classification. Floresta e Ambiente 19 (4): 468-474. - doi: 10.4322/flora m.2012.059

Halward A, Sanchez C (1975). Métodos de ensaios nas indústrias de celulose e papel [Test methods in the pulp and paper industries]. $\mathrm{Br}$ usco, São Paulo, SP, Brazil, pp. 75. [in Portuguese]

Hammer $\varnothing$, Harper DAT, Ryan PD (2001). Past: Paleontological statistics software package for education and data analysis. Palaeontologia Electronica 4 (1): 9. [online] URL: https://palae o-electronica.org/2001_1/past/past.pdf Higuchi T (1997). Biochemistry and molecular biology of wood. Springer Verlag, Berlin, Germany, pp. 362.

INPA/CPPF (1991). Catálogo de madeiras da Amazônia. Área da hidrelétrica de Balbina [Amazon timber catalog. Balbina hydroelectric area]. Instituto Nacional de Pesquisas da Amazônia INPA, Manaus, AM, Brazil, pp. 78. [in Portuguese]

IPT (2020). Wood Information. Instituto de Pesquisas Tecnologias - Web site. [online] URL: http://www.ipt.br/informacoes_madeiras3.php ?madeira=7

Kilic A, Niemz P (2012). Extractives in some tropical woods. European Journal of Wood and Wood Products 70: 79-831. - doi: 10.1007/s0010 7-010-0489-8

Kollmann FFP, Cotê Junior WA (1968). Principles of wood science and technology (vol. 2). Springer, Berlin, Germany, pp. 674. [online] URL: http://www.bcin.ca/bcin/detail.app?id=60996 Liu C, Zhang SY, Cloutier A, Rycabel T (2007). Modeling lumber bending stiffness and strength in natural black spruce stands using stand and tree characteristics. Forest Ecology and Management 242 (2-3): 648-655. - doi: 10.1016/j.foreco.2007.01.077

Lovaglio T, D'Auria M, Rita A, Todaro L (2017). Compositions of compounds extracted from thermo-treated wood using solvents of different polarities. iForest 10: 824-28. - doi: 10.3832/ ifor2360-010 
Mancini M, Leoni E, Nocetti M, Urbinati C, Duca D, Brunetti M, Toscano G (2019). Near infrared spectroscopy for assessing mechanical properties of Castanea sativa wood samples. Journal of Agricultural Engineering L 953: 191-197. - doi: 10.4081/jae.2019.953

Moutinho VHP, Couto AM, Lima JT, De Aguiar OJR, Nogueira MOG (2011). Energetic characterization of Matá-Matá wood from the brazilian rain forest (Eschweilera Mart Ex Dc). Scientia Forestalis 39: 457-461. [online] URL: http:// www.researchgate.net/publication/269519282 Nascimento CS, Varejão MJC (2012). NIR models for predicting chemical and physical properties of Amazonian woods - LQM/INPA (version 1:0 12). Web site. [online] URL: http://portal.inpa. gov.br/cotei/lqm

Nascimento CC, Nascimento CS, Brasil MM (2016). NIR models for predicting physico-mechanical properties of Amazonian wood LEAM/INPA (version 1:0-16). Web site. [online] URL: http://portal.inpa.gov.br/cotei/leam

Nascimento CC, Brasil MM, Nascimento CS, Barros SVS (2017). Estimation of the basic density of wood Eschweilera odora (Poepp.) Miers by near infrared spectroscopy. Brazilian Journal of Wood Science 8: 42-53. - doi: 10.12953/21776830/rcm.v8n1p42-53

Nascimento CS, Nascimento CC, Cruz IA, Araújo RD (2019). Perfil químico dos extrativos de espécies arbóreas da família Lecythidaceae [Chemical profile of extractives of tree species in the family Lecythidaceae]. In: Anais da "Semana Florestal - O Setor Florestal na Atualidade SF/UFAM" (Almeida NO ed). Manaus (AM, Brazil), 12-14 Nov 2019. UFAM, Manaus, AM, Brazil, pp. 10-15. [in Portuguese]

Nuopponen MH, Birch GM, Sykes RJ, Lee SJ, Stewart D (2006). Estimation of wood density and chemical composition by means of diffuse reflectance mid-infrared Fourier transform (DRIFT-MIR) spectroscopy. Journal of Agricultural and Food Chemistry 4: 34-40. - doi: 10.102 1/jfo51066m

OIMT (2015). Reseña bienal y evaluación de la situación mundial de las maderas 2013-2014 [Biennial review and assessment ofthe world timber situation 2013-2014]. Organización Interna- cional de las Maderas Tropicales - OIMT, Yokohama, KNG, Japan, pp. 145. [in Spanish]

Pizzi A (2019). Tannins: prospectives and actual industrial applications. Biomolecules 9 (344): 129. - doi: 10.3390/biom9080344

R Core Team (2020). R: a language and environment for statistical computing. R Foundation for Statistical Computing, Vienna, Austria. [online] URL: http://www.r-project.org

Santos ACM (2020). Influência do teor de extrativos na arquitetura hidráulica em espécies florestais da Amazônia Central [Influence of extractives content on hydraulic architecture in forest species in Central Amazonia]. Master's dissertation in Science of tropical forests, Instituto Nacional de Pesquisas da Amazônia, Manaus, AM, Brazil, pp. 93. [in Portuguese]

Schimleck LR, Matos JLM, Trianoski R, Prata JG (2018). Comparaison of methods for estimating mechanical properties of wood by NIR spectroscopy. Journal of Spectroscopy 2018: 1-10. - doi: 10.1155/2018/4823285

Serafimova E, Mladenov M, Mihailova I, Pelovski $Y$ (2011). Study on the characteristics of waste wood ash. Journal of the University of Chemical Technology and Metallurgy 46 (1): 31-34. [online] URL: http://www.researchgate.net/pu blication $/ 274249790$

Silva AC, Silva MBC (1991). Influência da anatomia e química nas propriedades da madeira [Influence of anatomy and chemistry on the properties of wood]. CEPEF/UTAM, Manaus, Brazil, pp. 55. [in Portuguese]

Silva DA, Almeida VC, Viana LC, Klock U, Muñiz GIB (2014). Evaluation of the energy - related properties of tropical wood waste using NIR spectroscopy. Floresta e Ambiente 21: 561-568. - doi: 10.1590/2179-8087.043414

Silva AP, Nascimento CC, Nascimento CS, Carmo MA, Araújo RD, Freitas JA (2020). Technological characterization of wood residues from the Amazon for the production of briquetes. International Journal of Advanced Engineering Research and Science 7 (9): 408-417. - doi: 10.2216 1/ijaers

Silveira LHC, Rezende AV, Vale AT (2013). Moisture content and basic wood density of nine commercial Amazonian tree species. Acta Ama- zonica 43: 197-184. - doi: 10.1590/So044-5967201 3000200007

Sjöström E (2013). Wood chemistry. Fundamentals and applications ( $2^{\text {nd }}$ edn). Academic Press, Espoo, Finland, pp. 293. [online] URL: http:// books.google.com/books?id=SvoxcS6eS5QC Soares AK, Lourenço TV, Delucis RA, Gatto DA (2018). Chemical composition and dimensional stability of three eucalypts wood. Matéria 23 (4): e12226. - doi: 10.1590/s1517-707620180004.0 560

Telmo C, Lousada J (2011). The explained variation by lignin and extractive contents on higher heating value of wood. Biomass and Bioenergy 35: 1663-1667. - doi: 10.1016/j.biombioe.2010.12 038

Todaro L, Rita A, Cetera P, D’Auria M (2015). Thermal treatment modifies the calorific value and ash content in some wood species. Fuel 140 (1): 1-3. - doi: 10.1016/j.fuel.2014.09.060

Tsuchikawa S, Schwanninger M (2013). A review of recent near-infrared research for wood and paper (Part 2). Applied Spectroscopy Reviews 48: 560-587. - doi: 10.1080/05704928.2011.621 079

Vale AT, Dias IS, Santana MAE (2010). Relationships among chemical properties, physical and energy wood properties of five cerrado species. Ciência Florestal 20: 137-145. - doi: 10.5902/ 198050981767

Varejão MJC, Nascimento CS, Cruz IA (2012). Avançando fronteiras: potencial químico, ecológico-econômico de espécies florestais de São Gabriel da Cachoeira, AM [Advancing frontiers: chemical, ecological-economic potential of forest species of São Gabriel da Cachoeira, AM]. In: "Desvendado as Fronteiras do Conhecimento na Região Amazônica do Alto Rio Negro" (Souza LAG, Guillermo-Castellón E eds). INPA - FRONTEIRAS, Manaus, AM, Brazil, pp. 5167. [in Portuguese] [online] URL: http://repo sitorio.inpa.gov.br/handle/1/34376

Yu L, Liang Y, Zhang Y, Cao J (2020). Mechanical properties of wood materials using near-infrared spectroscopy based on correlation local embedding and partial least-square. Journal of Forestry Research 31: 1053-1060. - doi: $10.1007 / \mathrm{s}$ 11676-019-01031-7 